$\xi_{p=-1}$

\title{
Synthesis, characterization, $x$-ray diffraction studies and biological activities of iron(III) and cobalt(II) complexes with alanine
}

\author{
Shuaibu Musa ${ }^{1 *}$, S. O. Idris ${ }^{1}$, A. D. Onu ${ }^{2}$ \\ ${ }^{1}$ Department of Chemistry Ahmadu Bello University, Zaria-Nigeria \\ ${ }^{2}$ Federal College of Education, Zaria-Nigeria \\ *Corresponding author E-mail: shuaibumusa@abu.edu.ng
}

\begin{abstract}
The resulted complexes produced between Fe (III) and Co (II) with biological molecules like amino acids play an important role in human life. They can be used as bioactive compounds as well as in industries. Fe (III) and Co (II) complexes are synthesized with Alanine amino acid. The complexes were characterized by X-ray diffraction, magnetic suscetivility, elemental analysis (AAS), molar conductance, melting point, infrared and uv-visible spectrophotometry analyses. The elemental analyses were used to determine the chelation ratio, 1:3(metal: ligands) for iron (III) Alanine and 1:2 ratio for cobalt (II) Alanine. The molar conductivity of the complexes show that the complexes are not electrolytic in nature. The x-ray data suggest monoclinic crystal system for all the complexes with the exception of Co-alanine, which is hexagonal. The magnetic susceptivility and electronic spectra suggest the complexes are high spin with octahedral geometry. The complexes show enhance activity in comparable to the amino acid.
\end{abstract}

Keywords: Synthesis; Characterization; X-Ray Diffraction; Electrolyte; Biological Activities.

\section{Introduction}

Interactions between transition metal ions and amino acids are very interesting in the biological applications and in catalysis. Complexes of some metals ions with amino acids can be used as models to study the pharmacodynamics effects of drugs or for increasing the biocompatibility and minimize toxic effects of some metal (Alshaheen et.al. 2014).

The transition metal complexes, which contain amino acid moieties, are an important class of ligands in coordination chemistry and have been widely reported (Raman et.al. 2007). Several transition metal complexes of amino acids have synthesized and characterized but their X-ray diffraction studies for the most part is not investigated, which is very important in the chemistry of inorganic and organometallic complexes, which give information about the crystalline phase, orientation and geometry of complexes. For this reason we are synthesizing these new complexes and focus on their X-ray diffraction studies and evaluate their biological properties.

However, in this paper, complexes of iron (III) and cobalt (II) are synthesized and characterized with elemental analysis, molar conductivity, electronic spectra, X-ray diffraction, magnetic susceptivility, FTIR analysis, and x-ray diffraction studies were carried out. The analytical data and the physical properties of the complexes are listed in Table 1 . The complexes can be represented by the formulae $\left[\mathrm{M}^{1} \mathrm{~L}_{3}\right]$ and $\left[\mathrm{M}_{2} \mathrm{~L}_{2} \mathrm{X}_{2}\right]$ where $\left[\mathrm{M}^{1}=\mathrm{Fe}\right.$ (III), $\mathrm{M}^{2}=\mathrm{Co}$ (II) $\mathrm{L}=$ alanine anion and $\mathrm{X}=\mathrm{H}_{2} \mathrm{O}$ ]. The complexes are stable in air and soluble in DMF and DMSO. The low molar conductance values of $10^{-3} \mathrm{M}$ solutions in DMSO (Table 1) indicate that all the complexes behave as non-electrolytes (Geary, 1971)

\section{Material and methods}

Experimental: All chemical were of reagent grade quality and were purchased from commercial sources (BDH and Fluka). They were used without further purification.

Physical characterization and x-ray diffraction studies: metal content analysis were made on Shimadzu AA670 atomic absorption spectrophotometer. Infrared spectra were recorded using the Fourier-Transform Spectrophotometer in the range $4000-200 \mathrm{~cm}^{-1}$ with $\mathrm{KBr}$ pellets. The electronic spectra were recorded on a Shimadzu UV160 for the $10^{-3} \mathrm{M}$ solution of complex in dimethyl- sulphoxide (DMSO) at $25^{\circ} \mathrm{C}$. Conductivity measurements were carried out with $10^{-3} \mathrm{M}$ solution of complexes in DMSO at ambient temperature using a Jenway 4070 conductivity meter. The magnetic measurements were carried out on the solids by manual magnetic susceptivility balance.

Anti-microbial screening: The compounds and the were screened using the disc diffusion method (CLSI, 2016)

The in vitro biological screening effects of the investigated compounds were tested against the bacteria MRSA, Escherichia Coli and Fungi Candida Albicans and A.niger. Stock solutions were prepared by dissolving the compounds in DMSO and serial dilutions of the compounds were prepared in sterile distilled water to determine the minimum inhibition concentration (MIC). The nutrient agar medium was poured into Petri plates. A suspension of the tested microorganism $(0.5 \mathrm{ml})$ was spread over the solid nutrient agar plates with the help of a spreader. Different dilutions of the stock solutions were applied on the $10 \mathrm{~mm}$ diameter sterile disc. 
After evaporating the solvent, the discs were placed on the inoculated plates. The Petri plates were placed at low temperature for two hours to allow the diffusion of the chemical and then incubated at a suitable optimum temperature for $30-36 \mathrm{hrs}$. The diameter of the inhibition zones was measured in millimeters ( Raman et.al., 2007)

\section{Synthesis of the complexes}

The complexes are synthesized by following a previously reported procedure with some minor modification. About $1.2 \mathrm{~g}$ of amino acid was dissolved in $20 \mathrm{ml}$ of warm distilled water and stirred with a stirring rod until the amino acid dissolved completely. About $0.4 \mathrm{~g}$ of metal salt $\left(\mathrm{CoCl}_{2} \cdot 6 \mathrm{H}_{2} \mathrm{O}\right.$ and $\left.\mathrm{FeCl}_{3} \cdot 6 \mathrm{H}_{2} \mathrm{O}\right)$ was dissolved in $25 \mathrm{ml}$ of distilled water until a brown for iron complexes and grey for cobalt complexes solution are formed. The two solutions were transferred into $500 \mathrm{ml}$ beaker and three drops $30 \% \mathrm{NaOH}$ is added for the amino acid deprotonation, with constant stirring under magnetic stirrer for about two hours. A brown for iron and grey for cobalt precipitated are formed, washed with ethanol and recrystallized on methanol and kept in a desiccator with percentage yield of 60-80 \% (Stanila et.al., 2008)

\section{Result and discussions}

The analytical data and the physical properties of the complexes are listed in Table 1 . The complexes can be represented by the formulae $\left[\mathrm{M}^{1} \mathrm{~L}_{3}\right]$ and $\left[\mathrm{M}^{2} \mathrm{~L}_{2} \mathrm{X}_{2}\right]$ Where

$\left[\mathrm{M}^{1}=\mathrm{Fe}(\mathrm{III}), \mathrm{M}^{2}=\mathrm{Co}\right.$ (II) $\mathrm{L}=$ Alanine anion and $\left.\mathrm{X}=\mathrm{H}_{2} \mathrm{O}\right]$.

Table 1: Analytical and Physical Data of the Synthesized Complexes

\begin{tabular}{|c|c|c|c|c|c|}
\hline $\begin{array}{l}\text { Com- } \\
\text { pound } \\
\mathrm{s} \\
\end{array}$ & $\begin{array}{l}\text { Co } \\
\text { lor }\end{array}$ & $\begin{array}{l}\text { Melt- } \\
\text { ing }\left({ }^{\circ} \mathrm{c}\right) \\
\text { point }\end{array}$ & $\begin{array}{l}\text { molar conduc- } \\
\text { tivity }\left(\Omega^{-}\right. \\
\left.{ }^{1} \mathrm{~cm}^{2} \mathrm{~mol}^{-1}\right)\end{array}$ & $\begin{array}{l}\% \text { of metal cal- } \\
\text { culated(ob- } \\
\text { served) }\end{array}$ & $\begin{array}{l}\lambda_{\max } \\
(\mathrm{nm} \\
) \\
\end{array}$ \\
\hline $\begin{array}{l}\text { ALA- } \\
\text { NINE }\end{array}$ & $\begin{array}{l}\text { W } \\
\text { hit } \\
\text { e }\end{array}$ & 258 & & & 250 \\
\hline $\begin{array}{l}\text { Fe- } \\
\text { ALA- } \\
\text { NINE }\end{array}$ & $\begin{array}{l}\mathrm{Br} \\
\mathrm{ow} \\
\mathrm{n}\end{array}$ & $287-290$ & 20 & $12.50(12.70)$ & 450 \\
\hline $\begin{array}{l}\text { Co- } \\
\text { ALA- } \\
\text { NINE }\end{array}$ & $\begin{array}{l}\text { Gr } \\
\text { ey }\end{array}$ & $269-270$ & 27 & $13.86(13.40)$ & 520 \\
\hline
\end{tabular}

\section{FTIR analysis}

The assignments have been done based on standard references and some published papers the characteristic bands of the complexes are listed in Table 2. The information about the metal coordination was obtained by comparing the IR frequency of the free ligands and the IR frequency of the iron(III) and Co(II) complexes.

In Alanine spectrum, N-H stretching vibration appears at $3052 \mathrm{~cm}$ 1 , and is shifted in the iron (III) Alanine complex to $3448 \mathrm{~cm}^{-1}$, which provide the involvement of $\mathrm{NH}_{2}$ in complex formation. The absorption band at $1608 \mathrm{~cm}^{-1}$ was attributed to $\mathrm{C}=\mathrm{O}$ stretching in the free ligands spectrum and shifted to $1627 \mathrm{~cm}^{-1}$ in the Iron- alanine complex which provide the involvement of oxygen in carboxylate group $\left(\mathrm{COO}^{-}\right)$in complex formation There is no band above $3450 \mathrm{~cm}^{-1}$ that indicates there is no water acting as ligands in the complex ( Stanila et.al., 2007).

However, for Cobalt Alanine complex N-H stretching vibration appears at $3425 \mathrm{~cm}^{-1}$, and is found at $3052 \mathrm{~cm}^{-1}$ in the free ligand, which provide the involvement of $\mathrm{NH}_{2}$ in complex formation. The absorption band at $1608 \mathrm{~cm}^{-1}$ was attributed to $\mathrm{C}=\mathrm{O}$ stretching in the free ligands spectrum and shifted to $1643 \mathrm{~cm}^{-1}$ in the Cobalt- alanine complex which provide the involvement of oxygen in carboxylate group $\left(\mathrm{COO}^{-}\right)$in complex formation There is band at $856 \mathrm{~cm}^{-1}$ that indicates there is water acting as ligands in the complex ( Bhagat et. al.,2012).
Moreover, the involvement of Oxygen and Nitrogen in the acid and amino groups respectively is further supported by the appearance of band around $432-486 \mathrm{~cm}^{-1}$ for M-O stretching, and around 535$700 \mathrm{~cm}^{-1}$ for M-N stretching (Nakamotp, 1988, Selwin et.al., 2006)

Table 2: Vibrational Frequencies $\left(\mathrm{Cm}^{-1}\right)$ of the Important Functional Groups in the Synthesized Complexes and Free Ligands

\begin{tabular}{llllll}
\hline Compounds & V N-H & V C=O & VM-N & VM-O & V OH, $\mathrm{H}_{2} \mathrm{O}$ \\
\hline ALANINE & 3052 & 1608 & & & \\
Fe-ALANINE & 3448 & 1627 & 601 & 486 & \\
Co-ALANINE & 3425 & 1643 & 671 & 439 & $(3560) 846$ \\
\hline
\end{tabular}

\section{Magnetic susceptibility results}

Magnetic moments of all the complexes were measured using a manual magnetic susceptibility balance (at $300 \mathrm{~K}$ ) are reported in table 3 . The measured values agree with the oxidation state of the metals. The effective magnetic moment values of the complexes demonstrate that all the complexes are sufficiently pure and no paramagnetic contaminations are present in the complexes. The complexes of Fe (III) and Co (II) are high spin paramagnetic as suggested by their magnetic moment values (Earnshaw, 1968, El-Behery et.al., 2007)

Table 3: Table below Summarizes the Magnetic Measurement Results for the Synthesized Complexes

\begin{tabular}{llll}
\hline Complex & $\begin{array}{l}\mathrm{X}_{\mathrm{g}} \times 10^{-} \\
5\end{array}$ & $\begin{array}{l}\mathrm{X}_{\mathrm{m}} \times 10^{-} \\
2\end{array}$ & $\begin{array}{l}\mu \text { eff Calculated (observed) } \\
(\mathrm{B} . \mathrm{M})\end{array}$ \\
\hline$\left[\mathrm{FeAl}_{3}\right]$ & 4.92 & 1.6 & $5.92(6.2)$ \\
{$\left[\mathrm{CoAl}_{2}\left(\mathrm{H}_{2} \mathrm{O}\right)\right.$} & 2.92 & 7.92 & $3.89(4.40)$ \\
$2]$
\end{tabular}

The values of the magnetic moments of these complexes are in the range (5.7-6.0) B.M for iron (III) and (4.3-5.2) for cobalt (II). Which are comparable with the values reported for octahedral iron (III) and Cobalt (II) complexes (Buttrus et.al. 2012) the literature value crystal field stabilization energy (CFSE) of these types of complexes is favorable for the formation of octahedral complex. So, the proposed geometry for all these Complexes is octahedral.

\section{X-ray diffraction result}

The X-ray diffraction pattern of these complexes compared with major peaks of relative intensity greater than $10 \%$ has been indexed to their hkl value by using computer program (Shyam et. al., 2016). The diffractogram of Fe(III) complex of alanine shows two reflections with maxima at $2 \theta=6.9^{\circ}$ corresponding to $d$ value $14.179 \AA$, the other reflection was at $2 \theta=16.1^{\circ}$ corresponding to $d$ value $5.306 \AA$, also the compound with similar crystal data from the xrd computer database is Iron magnesium alminium silicate

However, the diffractogram of Co (II) complex of alanine had eight reflections with maxima at $2 \theta=37.8^{\circ}$ corresponding to $\mathrm{d}$ value 5.471 $\AA$. Other reflections were at $2 \theta=16.1^{\circ}, 18.0^{\circ}, 32.5^{\circ}, 52.0^{\circ}, 53.0^{\circ}$, $57.6^{\circ}$ and $62.1^{\circ}$ with corresponding d value $4.72 \AA, 2.779 \AA, 2.388$ $\AA, 2.323 \AA, 1.782 \AA, 1.596 \AA$, and $1.510 \AA$ respectively, also the compound with similar crystal data from the database is beta cobalt hydroxide.

In respect of these cell parameters, these satisfies the condition to be required for sample to be monoclinic, such as $\mathrm{a} \neq \mathrm{b} \neq \mathrm{c}$ and $\alpha=$ $\gamma=90^{\circ} \neq \beta$. Hence it can be concluded that Fe (III) and Co (II), complex of alanine have monoclinic crystal system. The observed values fit well into the octahedral crystal system for all of the complexes.

\section{Biological activities}

The complexes were effective against both bacteria and fungi (table [4] and [5] respectively). The iron complex was better against both the gram positive and gram-negative bacteria and fungi when compared with the standard Drugs. Growth of bacterial pathogens on 
each concentration was checked to determine the minimum concentration that inhibits the growth of the organism (table 4 and 5)

Table 4: Microbial Inhibition Zone (Mm)

\begin{tabular}{lll}
\hline & Fungi & \\
\hline Compounds & C. Albicans & A. Niger \\
Valine & 6 & 20 \\
Fe-ALANINE & 40 & 30 \\
Co-ALANINE & 20 & 13 \\
FULCIN & 30 & 28 \\
\hline
\end{tabular}

Table 5: Microbial Inhibition Zone (Mm)

\begin{tabular}{lll}
\hline Compounds & MRSA & E.choli \\
\hline Valine & 6 & 6 \\
Fe-ALANINE & 29 & 26 \\
Co-ALANINE & 6 & 6 \\
Ciprofloxacin & 22 & 16 \\
\hline
\end{tabular}

\section{Conclusion}

- Molar conductivity measurements showed that the composition of the metal complexes correspond to a metal-ligand ratio of 1:2 for cobalt(II) complexes and 1:3 for iron(III) complexes.

- The IR spectra showed that the amino acids act as bidentate ligands with coordination involving the carboxyl oxygen and the nitrogen of the amino group. The result also suggests the presence of water of coordination in cobalt (II) complexes.

- $\quad$ Electronic spectra and magnetic susceptibility measurements suggested a six coordinate local symmetry around the complexes. Magnetic susceptibility studies also revealed that all the complexes are paramagnetic

- Powder XRD studies confirmed that the amino acid complexes are crystalline in nature and that they largely crystallized in monoclinic fashion. It also suggested that the bonding mode in the complexes is similar.

- The antimicrobial studies suggested that the amino acid ligands are biologically active and their metal complexes showed significantly enhanced antimicrobial sensitivity against the studied microbial strains in comparison to the free ligands

- $\quad$ The proposed structures of the complexes are as follows

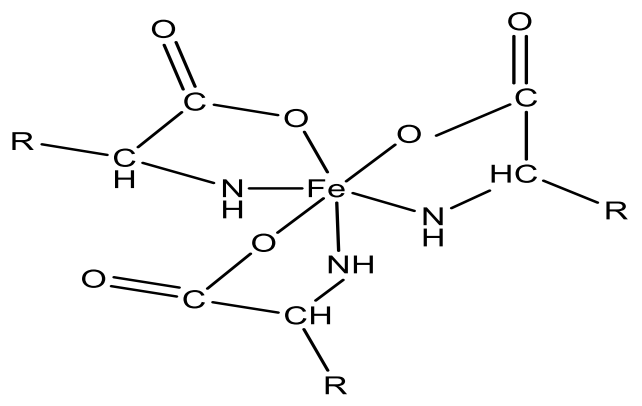

Fig. 1: Fe (Iii) Alanine.<smiles>[R]C(NC(O)(O)OC(=O)C([R])NC(=O)O)OC</smiles>

Fig. 2: Co (II) Alanine.

\section{Acknowledgements}

\section{References}

[1] Al-Shaheen J. Amira Al-Mula A. Miaa , 2014, "Schiff Base Complexes of Fe (III) Derived from Amino Acids", Research Journal of Chemical Sciences Vol. 4(8), 25-32

[2] A.Stanila,C.Nagag,A. Mercu, D.Cozma, D.Rusu, L.David,(2008), Spectroscopic investigation of new metallic complexes with Leucine as ligands pp.25-52.

[3] A.Stanila. Marcu A., Rusu D., Rusu M., David L. (2007), Spectroscopic studies of some copper (II) complexes with amino acids. J Mol Struct.834-836 https://doi.org/10.1016/j.molstruc.2006.11.048.

[4] Bhagat T.M., Swamy D.K. and Deshpande M.N., (2012), Synthesis and characterization of transition metal complexes with newly synthesized substituted benzothiazole, J. Chem and Pharm Research, 4, 100-104.

[5] Buttrus H.N. and Saeed T.F., (2012),Synthesis and Structural Studies on Some Transition Metal Complexes of Bis- (benzimidazole-2-thio) ethane, propane and butane ligands, Res. J. Chem. Sci., 2(6), 43-49

[6] Clinical and Laboratory Standard Institute, 2016. USA.

[7] Foex, G., Coiter, G., (1957). J. Constantes Selectionnees, Diamagnetismeet Paramagnetisme, Masson, Paris, a Collection of Diamagnetic and Paramagnetic Susceptibilities.

[8] El-Behery M and EI-Twigry H., (2007), Synthesis, Magnetic,Spectral and Antimicrobial Studies of $\mathrm{Cu}(\mathrm{II}), \mathrm{Ni}(\mathrm{II}), \mathrm{Co}(\mathrm{II}), \mathrm{Fe}$ (III) and UO2 (II) complexes of a new Schiff base hydrazone derived from 7 Chloro - 4- hydrazine quinoline, Spectro. Chim. Acta (A), 66, 28-36 https://doi.org/10.1016/j.saa.2006.02.017.

[9] El-Behery M and EI-Twigry H., (2007), Synthesis, Magnetic,Spectral and Antimicrobial Studies of $\mathrm{Cu}(\mathrm{II}), \mathrm{Ni}(\mathrm{II}), \mathrm{Co}(\mathrm{II}), \mathrm{Fe}$ (III) and UO2 (II) complexes of a new Schiff base hydrazone derived from 7 Chloro - 4- hydrazine quinoline, Spectro. Chim. Acta (A), 66, 28-36 https://doi.org/10.1016/j.saa.2006.02.017.

[10] Earnshaw, A., (1968). Introduction of Magnetochemistry. Academic Press, London

[11] Geary, W.J., (1971). Use of Conductivity Measurements in Organic Solvents for the Characterization of Coordination Compounds, Coord. Chem. Rev., Vol.3, pp.81-122. https://doi.org/10.1016/S0010-8545(00)80009-0.

[12] Nakamoto, K., (1988). IR and Raman Spectra of Inorganic and Coordination Compounds. third ed. John Wiley and Sons, NY, p.211

[13] Raman N., Dhaveethu Raja J. and Sakthivel A.,(2007), Synthesis, spectral characterization of Schiff base transition metal complexes: DNA cleavage and antimicrobial activity studies, J. Chem. Sci., 119 , 303-119 https://doi.org/10.1007/s12039-007-0041-5.

[14] Raman N., Dhaveethu Raja J. and Sakthivel A.,(2007), Synthesis, spectral characterization of Schiff base transition metal complexes: DNA cleavage and antimicrobial activity studies, J. Chem. Sci., 119 303-119 https://doi.org/10.1007/s12039-007-0041-5.

[15] R. Selwin Joseyphus, C. Justin Dhanaraj and M. Sivasankaran Nair, (2006), Synthesis and characterization of some Schiff base transition metal complexes derived from vanillin and L(+)alanine, Transition Metal Chemistry 31:699-702 Springer DOI 10.1007/s11243-0060048-7.

[16] Shyam R Annapure, Achut S Munde and Shantilal D Rathod.,(2016), Spectral, Thermal, X-Ray and Antimicrobial Studies of Newer Tetradentate $\mathrm{N}_{2} \mathrm{O}_{2}$ Schiff Base Complexes of First Transition Series, Pelagia Research Library Der Chemica Sinica, 7(4):47-54

Where $\mathrm{R}=\mathrm{CH}_{3}$ 